\title{
The Role of the Central Java Permadani in Preserving Javanese Culture
}

\author{
Joko Wasisto $^{1 *}$, Jumino ${ }^{1 *}$, and Ika Krismayani ${ }^{1^{*}}$ \\ ${ }^{1}$ Library Science Department, Faculty of Humanities, Universitas Diponegoro, Jalan Prof. Soedarto \\ Tembalang Semarang Indonesia
}

\begin{abstract}
The purpose of this research is to study and explore the role of the Central Java Permadani in preserving Javanese culture. Since 1984 the Central Java Permadani has committed to preserving Javanese culture, which is commonly called Javanese customs and traditions, such as Javanese wedding procedures and ceremonies, ruwatan, and traditional Javanese clothing. The role of the Central Java Permadani in preserving Javanese culture is done through two activities as its work program. The first is a structured activity, namely organizing Javanese Language Pranatacara and Pamedharsabda (Master of Ceremonies and speeches) courses in Javanese traditional bridal events. Second, it holds various activities temporarily to show Javanese customs and traditions that are still developing in Javanese society, such as performing Javanese traditional arts, holding mass rituals, and much more. The method used in this research is descriptive qualitative, with observational data collection, semi-structured interviews, and documentation studies. Data analysis was done through the stages of data collection, data reduction, data presentation, and concluding based on Miles and Huberman theory. The results show that the two Permadani activities above can preserve Javanese culture, although there are still challenges to face.
\end{abstract}

\section{Introduction}

Indonesia is an archipelagic country where the number of islands owned by the Indonesian state is very large. According to Hakim [1], the island which has a population density with a percentage of $60 \%$ of Indonesia's population lives on the island of Java. The large percentage results in the diversity of cultures that exist in[2]. Javanese culture was born from human intelligence. The intelligence referred to is the integration of the elements of "creativity, taste, intention" or what is commonly referred to as IQ (Intelligence Quotient), EQ (Emotional Quotient), and SQ (Spiritual Quotient). Javanese cultural work that originates from creativity, sense, and initiative, contains meaning or value, both religiously, historically, ethically (ethically), philosophically, aesthetically, as well as social, and economic values[3].

${ }^{*}$ Corresponding author: juminoya@,gmail.com 
Javanese cultural values also have a noble meaning for the Javanese people and have unique local wisdom. It is this local wisdom that needs to be preserved by all people to avoid the negative impacts of globalization. The impact of globalization is like a double-edged knife, because globalization has positive and negative impacts in various fields of life. One of the negative impacts of globalization is the degradation of local cultural values, one of which is Javanese culture. Report from the news perpustakaan.bsn.go.id, Bahrudin [4] states that one of the negative impacts of globalization is that it can erode the indigenous cultural values that exist in Indonesia.

To overcome the above problem, it is necessary to hold various cultural preservation activities. In line with Nahak [5] to maintain local culture as a national identity, there is a need for awareness from every level of society. One form of efforts to preserve Javanese culture can be done by establishing an organization committed to preserving Javanese culture, such as the organization of the Indonesian National Cultural Society Brotherhood (The Central Java Permadani). The Central Java Permadani is a social organization in the form of a foundation engaged in culture. The organization is committed to the preservation of Javanese culture which includes Javanese customs and traditions, such as Javanese bridal procedures and ceremonies, ruwatan, Javanese traditional clothing, Javanese language, Javanese traditional arts, Javanese philosophy, Javanese ethics, and so on[2].

Based on the explanations above, the problem in this study is focused on how the efforts made by the Central Javanese Permadani in preserving Javanese culture.

\section{Research Method}

The method used in this research is descriptive qualitative. A Qualitative research method is used to examine the conditions of natural objects, where the researcher is the key instrument. Data collection techniques are carried out by source triangulation, data analysis is inductive/qualitative by checking data from one source to another, and the research results emphasize understanding meaning, and constructing phenomena rather than generalization [6]. This descriptive qualitative method is under the research objectives, namely to study to explore the role of the Central Java Permadani in preserving Javanese culture. by collecting data by observation, semi-structured interviews to Mulyadi Purwa Atmaja, Setiadji Pontjowidjojo, Anwar Effendi, Soepono H. (13, 23, 24 February 2012), and documentation study, using Akta Pendirian Permadani, AD-ART Permadani and Dokumen Tri Niti Yogyo Permadani. Meanwhile, data analysis is performed using the "Analysis Interactive" model from Miles \& Huberman [7], which includes: data collection, data reduction, data presentation, and drawing conclusions.

\section{Discussion}

The Indonesian National Cultural Society Brotherhood (The Central Java Permadani) was officially established on July 4, 1984, in Semarang, reported from beritamagelang.id written by Rachma [8], Permadani is a social organization engaged in a culture that is open, public, and free from political influence. To maintain and preserve Javanese culture, Permadani implements work programs consisting of two types of work programs, namely:

1. Regular work program

The program is an activity planned and carried out periodically by Permadani as a means of realizing the objectives set out in the articles of association and by-laws. The form of regular activities is in the form of organizing Panatacara courses (master of ceremonies) and Pamedharsabda (speeches). This course is carried out to produce qualified people or experts in the fields of panatacara (presenter) and Pamedharsabda (giving 
speeches) in Javanese. According to Atmaja [9], this form of activity serves as a means to raise a sense of togetherness and solidarity from people in various social strata. Especially from people who still care about the existence of Javanese cultural arts from time to time continues to experience degradation.

2. Non-regular work program

The program is an activity carried out by Permadani on a temporal basis, which is seen as contributing to the realization of the goals of the Permadani organization. This activity takes various forms, for example, holding a Medhar Sabda competition, Javanese language courses, dance courses, cultural gatherings, kethoprak associations, ruwatan, Javanese clothing parades, and encouraging and motivating people's love for cultural arts.

In addition to the work program described earlier, the Central Java Permadani also has a mission that must be carried out, namely implementing the Tri Karsa Budaya (exploring, preserving, and developing national culture) [10]. To realize this mission, Permadani adheres to three basic principles of moral teachings, which are the Javanese way of life, namely Tri Niti Yogya or three teachings of goodness which include:

1. Memayu hayuning sasami, which means always trying to create inner and outer peace and tranquility in life together in society.

2. Dados of ladosing interpreters are bebrayan ingkang sae, namely being the best servant or servant in society.

3. Sadhengah Pakaryan Tansah has re-established Tiyang Sanes. This means that all attitudes and behavior should be able to provide a sense of pleasure and not harm others. The three moral teachings above are expected to influence and guide the attitudes/behavior of the people of the tapestry, both when they are in the family sphere or when they are doing activities together in the community. Besides, Permadani also adheres to three principles of brotherhood and togetherness, which originate from the spirit of mutual cooperation in Javanese society that is full of symbols[11]. The three principles of brotherhood and togetherness are referred to as the Tri Rukun, namely as follows:

1. Rukun Rasa; meanig to have the same feeling, namely the same attitude, the same perception, the same desire, and the same goal.

2. Rukun Bandha; namely using mutual assistance in carrying a burden, especially those related to funds or finances.

3. Rukun Bala; the point trying to build togetherness in work which is based on the bonds of brotherhood.

The two basic principles of Sarwa Tri are the "spirit" or soul of Permadani management. All abilities can be encouraged and deployed by synergizing the various functions contained in the Permadani organization so that the hopes of Permadani can be realized.

\section{Conclusion}

Permadani is a community organization that operates in the field of culture that is open, public, and free from political influence. To maintain and preserve Javanese culture, Permadani conducts work programs consisting of two types of work programs, namely regular work programs (Panatacara and Pamedharsabda) and non-regular (Medhar Sabda competition, Javanese language course, dance course, cultural workshop, kethoprak association, ruwatan, Javanese clothing parade, as well as encouraging and motivating people's love for arts and culture). Permadani also has a mission that must be carried out, namely implementing the Tri Karsa Budaya (exploring, preserving, and developing national culture). To realize this mission, the Central Java Permadani adheres to three basic. principles 
of moral teachings, namely Tri Niti Yogya and adheres to three principles of brotherhood and togetherness, namely Tri Rukun.

\section{References}

[1] I. Hakim, "5 Pulau Terbesar di Indonesia," 2020. .

[2] A. Khairina and N. S. Lestari, "Environment on Javanese Literary Work: Exploring Cultural Convention and Harmony of Thinking," IOP Conf. Ser. Earth Environ. Sci., vol. 469, no. 1, 2020, doi: 10.1088/1755-1315/469/1/012053.

[3] N. C. Idham, "Javanese islamic architecture: Adoption and adaptation of javanese and hindu-buddhist cultures in indonesia," J. Archit. Urban., vol. 45, no. 1, pp. 9-18, 2021, doi: 10.3846/jau.2021.13709.

[4] M. Bahrudin, “Apa Saja Dampak Positif-Negatif Globalisasi di Bidang Sosial Budaya," 2021. .

[5] H. M. . Nahak, "Upaya Melestarikan Budaya Indonesia Di Era Globalisasi," J. Sosiol. Nusant., vol. 5, no. 1, pp. 65-76, 2019, doi: 10.33369/jsn.5.1.65-76.

[6] Sugiyono, Metode Penelitian Kuantitatif, Kualitatif, dan $R \& D$. Bandung: ALFABETA, 2013.

[7] M. B. Miles and A. M. Huberman, Qualitative data analysis: an expanded sourcebook, 2nd ed. SAGE Publication, 1994.

[8] F. Rachma, "Permadani Kabupaten Magelang Gelar Wisuda Bregada," beritamagelang.id, Oct. 2018. .

[9] M. P. Atmaja, Wawancara Pribadi, vol. 2012, p.

[10] A. Effendi, "Peran Aktif 'Permadani' dalam Pendidikan Budi Pekeri bagi Generasi Masa Kini," Oct. 2017.

[11] O. Y. Pamungkas, S. T. Widodo, S. Suyitno, and S. Endraswara, "Javanese cosmology: Symbolic transformation of names in javanese novels," HTS Teol. Stud. / Theol. Stud., vol. 77, no. 4, pp. 1-7, 2021, doi: 10.4102/hts.v77i4.6593. 